\title{
Spine Osteoarthritis
}

\author{
Elizabeth Pérez-Hernández, \\ Nury Pérez-Hernández and Ariel Fuerte-Hernández
}

Additional information is available at the end of the chapter

http://dx.doi.org/10.5772/60940

\section{Introduction}

Osteoarthritis (OA) is a widespread disease and is considered the most common form of arthritis. The current OA prevalence is estimated at $15 \%$ of the population [1], but this rate is predicted to double by 2020 [2] and this increase is related with some lifestyle diseases like obesity [2]. OA affects the joints of the hand and the lower extremities such as knee and hip. OA of the spine occurs in approximately $40-85 \%$ of the adult population, but it is often omitted in prevalence studies. The rate disparities are due to the differences on the definition of the disease and to the variability between demographic groups studied [3]. Generally, the costs for OA care are high, as well as the economic implications for prolonged work disability [4, 5]. Symptomatically, it is considered that $80 \%$ of Americans suffer an episode of low back pain (LBP) in their lifetime [6, 7], thus care costs for LBP are estimated to be more than 100 billion dollars per year in the US [8], with a loss of 149 million workdays per year [9, 10].

OA of the lumbar spine is related with the degeneration of the intervertebral disc (ID) and bone formation, which is called spondylosis [11]. There has been a lack consensus on whether or not the combination of decreased disc space and osteophyte formation is a characteristic of OA or is a separate phenomenon. Clinically, the association between OA of the hand, knee and facet joint has been described, but no relationship was found between disc degeneration (DD) and OA of the hip, knee, or hand, or between the formation of osteophytes and OA of the hip and hand [12].

OA is defined as a disease resulting in structural and functional failure of synovial joints, which usually is characterized by progressive articular cartilage damage, involvement of the synovium and subchondral bone hypertrophy. OA affects the spinal zygapophyseal joints and is closely related to degenerative disc disease (DDD) despite the pathophysiological differen- 
ces between the two disorders [13]. This degenerative cycle has mechanical impact with significant and progressive changes in the functional anatomy and mechanobiology, manifesting pain syndromes, destabilization, and impaired quality of life.

\section{Anatomy and mechanics of the spinal joints}

\subsection{Normal facet joints}

The vertebral joints are complex structures made up of posterior and anterior elements. The posterolateral spine consists of facet joints that are considered true synovial joint. One ID and two facet joints comprises a "three-joint complex." This complex binds two adjacent vertebrae, and the superior articular process of the inferior vertebra joins with the inferior articular processes of the overlying vertebra (Figure 1). The joint surfaces in the cervical and thoracic spinal regions are convex and concave, and the lumbar region of the facet joints shows a devastated form [14]. The orientation of the articular surfaces has a basic biomechanical role. The articular surfaces of the cervical and thoracic spinal segments are arranged horizontally $[14,15]$, favoring the axial rotation and lateral flexion [16, 17]. Comparatively, lower thoracic and lumbar spinal regions tend to adopt a more vertical orientation [18] that limits lateral flexion and rotation, protecting the IDs and spinal cord. Generally, the inclination angles of cervical facet joints in the sagittal plane ranges from $20^{\circ}$ to $78^{\circ}$ and in the axial plane from $70^{\circ}$ to $96^{\circ}$, while the angle between the thoracic facet joints range from $55^{\circ}$ to $80^{\circ}$ and $85^{\circ}$ to $120^{\circ}$, and the lumbar region range from $82^{\circ}$ to $86^{\circ}$ and $15^{\circ}$ to $70^{\circ}$ in both planes, respectively $[14,18]$.

Typically, facet synovial joints have a hyaline cartilage cover, subchondral bone, synovium, and a ligament system that envelops the entire joint $[19,20]$. The cartilage layer is thinner at the edges of the joint surface and gradually thicker in the central portion thereof [21]. The composition of the articular cartilage does not differ from that observed in other diarthrodial surfaces, a cellular component, chondrocytes, and an abundant extracellular matrix (EM) composed of water, fibrillar proteins, glycosaminoglycans, and proteoglycans. The mechanical properties, such as load distribution and low-friction movement are dependent on the articular cartilage integrity $[22,23]$.

The subchondral bone has been considered as a morphological unit that provides a link between the articular cartilage and cancellous bone, which plays a key role in mitigate the impact of axial forces during dynamic joint load [24, 25]. It has been reported that the subchondral bone thickness is greater in asymptomatic males and increases with each successive lower spinal level, suggesting its association with the increased load [25].

Additionally, synovium and the ligament system facilitate movement with minimal friction and provide mechanical resistance, while synovial fluid lubricates and nourishes the joint surfaces [26]. The meniscoides or intraarticular synovial folds also protect the articular cartilage during movement [27], compensate the irregularities of the joint surface and increase the contact surface with the facets [28]. The meniscoides are formed by fatty, fibrous connective tissues and a lining of synovium [29,28]. 


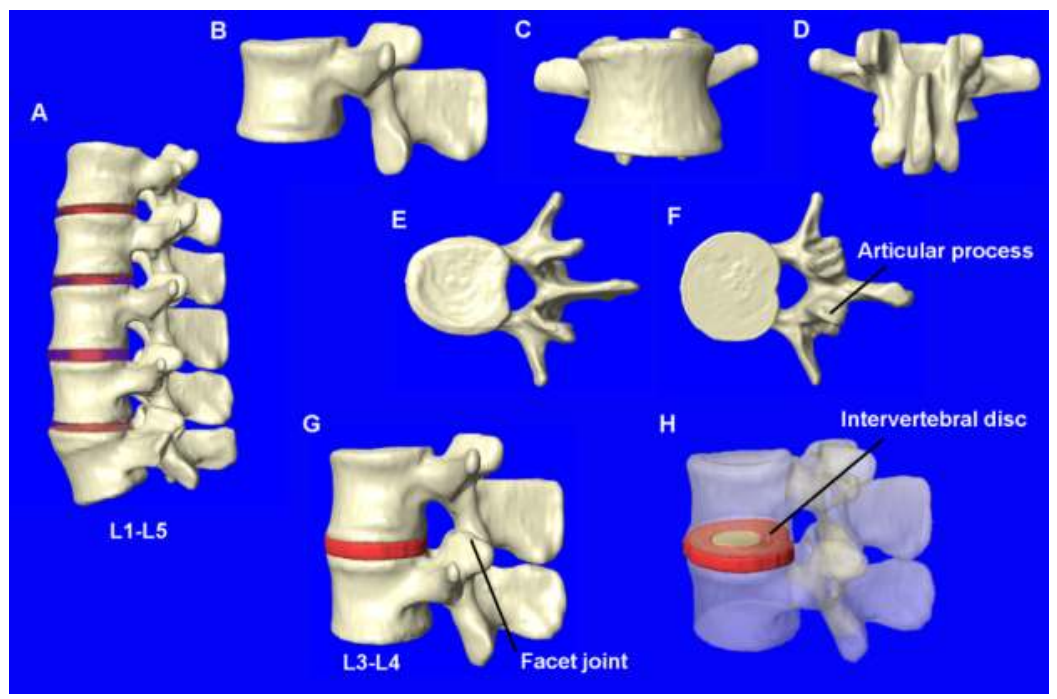

Figure 1. Normal anatomy of the facet joint and ID. A. Sagittal view of segments L1-L5; B. Sagittal view (L3); C-D. Coronal views (L3); E-F. Axial view (L3); G. Lumbar disc-facet unit (L3-L4); H. ID (L3-L4).

Moreover, the capsule comprises ligament fibroblasts, dense collagen fibers, elastic fibers, and proteoglycans [30,31], and one of its main functions is to allow movement without provide mechanical resistance.

\subsection{Normal intervertebral disc}

In the anterior spine, the vertebral bodies are attached through the IDs. These structures provide support for load and flexibility during mechanical exposure; they also facilitate the movements of flexion, extension, and rotation. The typical composition of the ID consists of a central nucleus pulposus, which is contained in an outer annulus fibrous at the periphery, and the inferior and superior cartilage endplates [32].

Annulus fibers are agreed in concentric lamellae and consist predominantly of type I collagen [33]. In the early stages of life, these lamellae are arranged regularly, these are divide and interdigitate, and during aging they form an intricate and complex network in response to the load. Adult lumbar discs may contain up to 25 lamellae, thus lead to an increase in thickness toward the center portion thereof [34]. Annulus cells are small, elongated, disposed parallel to lamellae, and synthesize types I and II collagen [35], elastin [36], proteoglycans [37], and types III, IV, and VI collagens in various proportions [38, 39, 40, 41]. Other proteins with leucine-rich repeat, such as fibromodulin, decorin, and lumican, regulate the assembly of collagen fibers; similarly, the cartilage oligomeric matrix protein (COMP) is involved in regulation of the assembly of fibrillar proteins. Furthermore, chondroadherin, other protein 
with leucine-rich repeat without carbohydrate substituents and without the N-terminal binds to collagen participates in the maintenance of chondrocyte phenotype [41].

The center of the ID is the nucleus pulposus, which becomes gelatinous and more fibrous with aging. The nucleus pulposus is surrounded by a fibrous capsule and consists of round or oval chondrocyte-like cell with abundant cytoplasm and prominent cytoskeleton. These cells are called "physaliphorus" cells, which present large vacuoles. In this region, these cells are responsible in the synthesis of type II collagen [35]. The nucleus pulposus is rich in proteoglycan aggrecan, which consists of approximately chondroitin sulfate chains hundred, and each polysaccharide chain has about hundred negatively charged groups. Furthermore, the keratan sulfate chains are disposed in clusters located in a different area to that of chondroitin sulfate chains. Moreover, hundred molecules bind aggrecan and hyaluronate, as well as fibulin and tenascin proteins $[41,42]$. These negatively charged macromolecular structures promote osmotic water retention.

The interface between the disc and the vertebral body consists of a thin layer of hyaline cartilage called endplate. This is extended across most of the vertebral body except at the outer rim, where the fibers of annulus fibrosus are inserted. In adults, this tissue is avascular, so the metabolites diffuse through it to the cells of the endplate and the center of the disc. During adulthood, the endplate thickness is reduced to approximately $0.6 \mathrm{~mm}$ [43]. Biochemically, the endplate contains type $X$ collagen, which is involved in calcification processes [44].

It is well known that the main source of energy disc cells is derived from glycolysis [45]. Due to the low oxygen tension, protein synthesis and macromolecules, such as sulfated glycosaminoglycans is inhibited. Stimuli such as growth factors also come from the extracellular fluid [46], while the ATP production in disc cells depends on the local $\mathrm{pH}$ and nutrient availability. Most studies have reported that an acidic $\mathrm{pH}$ level significantly reduces the glycolytic metabolism and the rate of oxygen consumption, with concomitant decrease in ATP production $[47,48]$. However, the effect of oxygen concentration in disc cells remains controversial, as some studies have described a positive effect $[45,46]$. Protein synthesis is also a process affected by local oxygen and $\mathrm{pH}$ levels, which significant decrease if the low oxygen tension to less than 5\% [46]. Similarly, extracellular $\mathrm{pH}$ affects protein synthesis, so an abrupt decrease in acidic environments [48]. Contrary to this event, the activity of matrix metalloproteinases is generally not inhibited at low $\mathrm{pH}$, which may enhance the rate of matrix breakdown [49].

Dependent glucose supply (primary energy source), disc cells can die within 24 hours if glucose concentrations fall below $0.2 \mathrm{mM}$. Under these conditions, the intracellular glucose transport is also significantly reduced [50]. In this respect, it has been reported that the rate of cell death of the disc increases in acidic conditions ( $\mathrm{pH}$ 6.0) despite of an adequate glucose intake [51,52].

The avascular nature of the adult human ID is well known, with minimal penetration of capillaries and nerve endings in the outer regions of the annulus. This capillary network comes from the vertebral arteries which across the subchondral bone forming the loops of the interface between cartilage endplate and the bone $[53,54]$. Thus, vascularity is protected by the cartilage endplate and promotes selective transport of molecules through the disc $[55,56]$. 
Nutrients diffuse from capillary vascularity of the disc, through cartilage endplate, EM until the cells $[57,58,59]$. This solute movement is associated with load patterns to which it is usually subjected the disc. Apparently, the mechanical load on the disc is inversely proportional to nutrient transport. For example, during the redistribution of the load, the disc thickness is decreased, favoring the transport of nutrients from the cartilage endplate; however, if the proportion of fluid in the tissue matrix is decreased, diffusion is reduced, and this could affect the metabolic levels $[60,61]$. This charge-nutrients ratio in the ID is still under investigation. Diffusion gradient, which is dependent on passive transport, leads to differences in the metabolic activity of the disc cells. Generally, the center of the disc contains lower concentrations of glucose and oxygen, and higher concentrations of lactic acid [45].

\subsection{Mechanobiology}

The mechanical load on the ID can cause multiple physical changes and mechanobiological effects. Volumetric changes, fluid flows, pressure changes, electrokinetic activity, and changes in cell shape are events that occur secondarily to tension, compression, or shear. Previous studies in vitro and in vivo on animal models have shown that the static compressive load or strain (0.2 to $0.4 \mathrm{MPa}$ ) [62] can induce anabolic cellular responses in the disc, with increased gene expression and synthesis of EM components such as proteoglycans and types I and II collagens [63].

Comparatively, during dynamic compression at low frequency $(0.01 \mathrm{~Hz}, 1 \mathrm{MPa})$ in cells of rodent disc, induce an increase in the gene expression of macromolecules such as aggrecan and types I and II collagens. At higher frequencies of load an increase in expression of mRNA of proteases like MMP-3, MMP-13, ADAMTS-4 (a disintegrin and metalloproteinase with thrombospondin motifs) has been observed [64,65]. Additionally, disc cell death occurred after exposure to high magnitudes $(>0.4 \mathrm{MPa})$ and low frequency $(0.01 \mathrm{~Hz})$ of dynamic load.

In response to moderate hydrostatic pressure $(<3.0 \mathrm{MPa})$, the cells cultured or tissue explants of disc may increase the synthesis collagen, proteoglycans, and tissue inhibitor of metalloproteinase 1 (TIMP1), which applies to cells of the nucleus pulposus and annulus inner regions $[66,67,68]$. The inhibition of protein synthesis, the increase in the nitric oxide and the synthesis of MMP-3 have been shown in disc cells in extreme downward or high pressures [69].

Similarly, the metabolic activity of the disc cells has been influenced by changes in osmotic pressure. In vitro tests have shown high rates of proteoglycan synthesis at in situ extracellular osmolarity ( $430 \mathrm{mOsm})$; however, when this concentration is increased or decreased, protein synthesis declines [70]. Another manifestation of compressive deformation of disc cells is the reorganization of the cytoskeleton, including the increase of early polymerization of vimentin [63]. Also depolymerization of actin filament calcium-dependent and the volume change on disc cells grown in hyper or hypo-osmotic media has also been shown [71, 72].

Moreover, disc cells exposed to stress in vitro undergo changes in the membrane potential associated with apoptosis. These cells increase nitric oxide production and decrease the proteoglycans synthesis [73, 74]. 


\section{Epidemiology}

\subsection{Facet arthrosis}

LBP is considered epidemic, and its prevalence varies in developed countries from $60 \%$ to $90 \%$ of patients undergoing orthopedic consultation [75, 76]. The cost of care for these patients varies from $\$ 100$ to $\$ 200$ billion annually [8]. One of the main causes of LBP is facet arthrosis. Since 1930, it has been called as facet syndrome [77, 78]; many studies on cadavers have described the presentation of facet arthrosis around the third decade of life [79, 80]. According to epidemiological studies based on imaging, the cervical facet OA has been reported in $19 \%$ of adults between 45 and 64 years of age and in $57 \%$ of adults over 65 years [81]. On severe lumbar facet OA diagnosed by computed tomography (CT) images, prevalence rates are estimated to be $36 \%$ in adults under 45 years of age, $67 \%$ in adults between 45 and 64 years, and $89 \%$ in individuals over 65 years [82]. Thus, it can be concluded that the prevalence of facet $\mathrm{OA}$ and its progression are dependent on age [81, 83].

The literature reports higher prevalence and degree of arthrosis at L4-L5 facet joints [79, 84, 85]. This was more prevalent at L4-L5 (from $45.1 \%$ to $79 \%$ ), followed by L5-S1 (from $38.2 \%$ to $59 \%$ ), and finally L3-L4 (from $30.6 \%$ to $72 \%$ ) [79, 84]. These reports support the fact that the degenerative lumbar stenosis is related to the more mobile segments (L3-L4, L4-L5) of the lumbar spine [86, 87]. On the frequency of occurrence on the right or left side, an equal distribution has been reported [88].

With respect to gender, higher prevalence has been reported in males, and apparently, there is no significant difference in relation to race $[79,80]$. However, in image studies using CT scans and planar radiography, women have been shown to have a higher prevalence of lumbar facet OA than men [12].

Moreover, the body mass index (BMI) has been found to be associated with an increased prevalence of cervical facet $\mathrm{OA}[83]$ and, even more, of the lumbar region [12, 82]. In this respect, the risk of lumbar facet $\mathrm{OA}$ is almost three times higher in overweight individuals (BMI $25-30 \mathrm{~kg} / \mathrm{m}^{2}$ ) and five times more associated with obesity (BMI $30-35 \mathrm{~kg} / \mathrm{m}^{2}$ ), in comparison with the normal-weight reference group $\left(\mathrm{BMI} \leq 25 \mathrm{~kg} / \mathrm{m}^{2}\right)$ [12].

Another risk factor for facet $\mathrm{OA}$ is the anatomy of the spine; for example, the changes in the orientation of the articular facet and facet joint asymmetry or "tropism" [89, 90, 91, 92] and simultaneously the disc-height narrowing represents the risk of contracting the disease [82]. Similarly, other factors such as the poor quality of the extensor muscles have been associated with facet OA of L4-L5 [93].

\subsection{Disc degeneration}

Although there is no standard definition of disc degeneration (DD), it is considered the product of the degradation and remodeling of the ID and adjacent vertebrae, with adaptive changes and/or consequential damage induced by physical load. Radiographic studies, particularly 
magnetic resonance imaging (MRI), have allowed qualitative assessment of disc degeneration (DD). Particular emphasis has been given on disc space narrowing, the disc-vertebra remodeling with formation of osteophytes and disc bulge peripherals, changes or loss of signal intensity with development of annular tears, herniations, Schmorl nodes, and endplate sclerosis $[94,95]$. In this regard, the prevalence of disc-bulging has been described from $10 \%$ to over $80 \%$ in asymptomatic patients, and the prevalence of annular tears varies from $6 \%$ to $56 \%$ [3].

Age has been widely related to disc degeneration (DD). Degenerative changes have been described since childhood and young adulthood, such as the presence of annular tears between 3 and 10 years old $[96,97,98]$. Moreover, the water content of the nucleus pulposus shown by the disc signal intensity has been reported from 35 years of age [99].

It has also been proposed that mechanical load and nutritional states could contribute to the early development of DD, and it has found more severe in men than in women [100]. The association of heavy physical load and DD is still controversial and inconsistent. Similarly, relation to smoking has not been found [99].

Studies on the genetic influence in monozygotic male twins have shown a substantial familial influence on disc degenerative changes such as lumbar disc-height narrowing, bulging or herniation, and disc desiccation [99, 101, 102]. It seems likely that the DD is a multifactorial genetic condition, oligogenic. Some of the human gene forms reported as TaqI and FokI of the vitamin-D receptor gene have been associated with low intensity of magnetic resonance signal of thoracic and lumbar discs [103]. Two genotypes of MMP-3 gene have been related with degenerative disc changes in the elderly, and type IX collagen, alpha 2 (COL9A2), and 3 (COL9A3) gene forms have been linked with symptomatic disc pathology [104]. Nevertheless, research in this is still lacking.

\section{Pathophysiology}

\subsection{Mechanical response and degeneration}

DD is the manifestation of damage set caused by heavy physical load, posture or improper movement, and vibration. Therefore, it is extremely important to know the mechanical consequences of spinal motion segments under conditions of cyclic load, load magnitude, and frequency [105]. The investigations on degenerative mechanisms have been greatly supported in numerical models of the disc in animals, such as a finite element model [106]. One of the main advantages of the finite element model is the ability to parametrically manipulate one input factor and evaluate the resulting effects. These models have improved gradually, with the inclusion of poroelastic material properties of the motion segment facilitating the evaluation of physiological parameters related to cyclic load [107].

The application of the models in the evaluation of DD include analysis of disc geometry and mechanical properties of the nucleus, changes in permeability, porosity, and water content. 
The decreased content of fluid that occurs in degenerative processes is known to affect not only the nucleus pulposus but also the annulus matrix resulting in disc stiffness [106, 108, 109]. Poroelastic finite models have allowed evaluation of the effect on the strain-dependent permeability and osmotic potential in cyclic compression and expansion [110, 111]. These studies have shown time-dependent deformation of a lumbar motion segment subjected to multiple creep-compression-expansion loads. Another study that used an asymmetric discbody-disc poroelastic finite element model has shown that sustained compression maintains tensile stresses in the outer portion of the annulus but not in the middle and inner regions [108]. This correlates with the progressive disruption of the annulus fibrosus observed in vivo as well as the increase in apoptosis and the consequent decrease of cellularity. Similarly, other authors have demonstrated changes in the density and distribution of electric charges in healthy versus degenerated discs, which induced stress, water loss, and nutritional implications $[59,112]$.

A poroelastic finite element model determines the interaction of fluid with the proteoglycans in the nucleus. Using this model, it has been shown that normal discs are much more deformable that discs degenerate in response to cyclic load. The loss of healthy disc height in load cycle at a maximum load of $2000 \mathrm{~N}$ varied between $2.5 \mathrm{~mm}$ and $4.5 \mathrm{~mm}$ as opposed to between $1.0 \mathrm{~mm}$ and $1.8 \mathrm{~mm}$ in the degenerated disc $[107,113]$. Similarly, stiffness of the disc was shown to be inversely proportional to the load cycles, while under higher compression loads (3000 $\mathrm{N})$, loss of healthy disc height was demonstrated in $48 \%$ in comparison with $40 \%$ in degenerated discs [108].

Additionally, the poroelastic finite element model can predict the evolution of disc failure. A previous study showed that disc failure is propagated when the elastic modulus is decreased and the rate of disc failure associated with increase load was greater than that due to decrease in elastic modulus [107].

\subsection{Intervertebral disc aging and degeneration}

DD is a process related to physiological conditions, such as aging in most asymptomatic individuals, and is associated with pathological processes involving pain and disability. The definition of DD has not been fully established; two possibilities have emerged: one in which degenerative disc changes correspond to premature aging, and the other in which there is similarity between DD: and age changes but at an accelerated rate [114, 115]. It is possible that changes in the spine associated with aging are genetically predetermined and/or are associated with exposure to heavy mechanical forces throughout life. Independent of the trigger mechanism, degenerative changes begin with biochemical alterations, followed by structural changes of the spinal functional units [116].

The notochordal cells constitute the primordium of the nucleus during the development of the ID and generally decrease in number rapidly after birth $[117,118]$. Gradually, cellularity of the nucleus pulposus is replaced by chondrocyte-like cells, which may originate and migrate from the cartilaginous endplate and inner annulus [119]. Apparently, the Fas-mediated apoptosis 
plays an important role in this process [120]. The notochordal cells synthesize more proteoglycans than chondrocytes and might be responsible in maintaining the fluid gelatinous nucleus pulposus [121]. Due to the reduction of these cells, the nucleus pulposus becomes more solid cartilage, which also decreases the signal intensity on MRI. On cell density, some studies have suggested an increase in the proportion of cells in the inner annulus fibrosus and the nucleus pulposus $[122,123]$.

The normal ID maintains a balance between synthesis and degradation of EM components, but it is well known that the age-related early degenerative changes are loss of aggrecan, collagen, and water in the nucleus pulposus. In addition, the release of molecules, including proinflammatory cytokines such as interleukin 1 (IL-1) and tumor necrosis factor- $\alpha$ (TNF- $\alpha$ ) $[124,125]$, increases the synthesis of metalloproteinases [126] contributes also to this degenerative process. However, it is noteworthy that annulus cells in the early stages of DD synthesize a larger amount of proteoglycans and collagen, probably in response to a repair process [127]. The progress of degeneration involves the reduction of production of most of the molecules of the EM, except for biglycan and fibronectin [127].

Generally, degenerative disc changes are of multifactorial origin. One of the most important determinants is the nutritional deficit secondary to decreased blood supply to the endplate. Apparently, this process could start early in the second decade of life [97]. Vascularization and innervation of the disc are also associated with aging and degeneration. Similarly, inflammatory cells and macrophages have been identified in degenerated discs and have been found responsible in the synthesis of cytokines and proteases by endogenous cells and by the vascular cells of the invading vessels [128]. The painful sensation that accompanies DD associated with aging is due to the presence of nociceptive nerve fibers in the annulus and inner nucleus [129].

Additionally, macroscopic changes can be observed, as well as concentric fissures and radial tears in the annulus from the third and fourth decades of life [130]. These modifications are due to increased synthesis of metalloproteinases that occurs as a result of the advance of age [130].

Besides, cell viability is also affected in aging due to thinning and calcification of the endplates, which impair the nutritional contribution of the disc [131]. Also, other factors like stress induced by overload or nonphysiological static compression and cyclic stretching are involved in cell death and DD $[65,74,108,132,133,134]$. Furthermore, there are reports of cell proliferation in human degenerative discs especially in areas where cell clusters are integrated [135].

\subsection{Facet articular $\mathrm{OA}$ and aging}

The degenerative processes associated with age or other factors may also affect the facet joint indirectly. These changes are usually associated with variations in the load surfaces of the joint [136]. This can manifest macroscopically with osteophytes and bone overgrowth with stenosis of the foramen, lateral and central spinal canal [85, 88, 90, 137, 138, 139]. Previous studies reported that the subchondral cortex shows no significant morphological variation in different spinal levels as a result of aging, suggesting that it may be due to a slower rate of remodeling. 
Moreover, the fraction of bone volume and trabecular thickness decrease is more frequent in women than in men during aging [140].

It is generally accepted that degenerative facet changes are preceded by DD [137, 141]. We already mentioned that the consequences of DD include segmental instability and increase in facet load, which could induce joint subluxation and damage the cartilage surface. The changes in the cartilage are characterized by progressive erosion and subchondral bone sclerosis. Degenerative changes of facet articular are identical to OA seen in other synovial articulations. In addition to facet hypertrophy, apophyseal misalignment and osteophyte formation may narrow the spinal canal. Also, involvement of the triple articulation can influence degenerative spondylolisthesis and scoliosis [116].

Bone also undergoes sclerosis with consequent redistribution of loads, which may progress and induce bone remodeling and subsequent rotatory deformities of the posterior elements [142].

\section{Spinal pain}

\subsection{Lumbar facet syndrome and cervical facet pain}

The facet joints are often associated with neck pain and LBP. The mechanical painful stimuli have been detected in sensory fibers, nociceptive endings, sensory afferent nerve endings, and types III/A and IV/C fibers located in the joint capsule, ligaments, periosteum, and subchondral bone [143, 144].

Neurophysiological studies have shown the involvement of small-diameter sensory neurons of the capsule, facet sensory neurons during inflammation and the effect of substance $P$ in lumbar facet pain $[145,146,147]$. Furthermore, it has been demonstrated that substance $\mathrm{P}$ is also contained in nerve endings of subchondral bone in patients with facet OA [148].

The prevalence of cervical facet pain has been reported in about $55 \%$ of patients with chronic nonspecific pain [149]. Previous studies have suggested that the cervical facet pain signals are derived from the capsule, where the immunoreactivity of substance $\mathrm{P}$ and calcitonin generelated peptides has been demonstrated [150]. Several mechanisms have been proposed in facet joint injury including facet-joint impingement, synovial pinching, and strain injury to the capsule [151, 152, 153, 154, 155]. In this regard, it was deduced that noxious and trigger nociceptive discharges from the capsule are transmitted to the central nervous system for pain sensation [155]. This response was seen not only as a result of the injury but also secondary to high-magnitude mechanical stimuli such as tension, compression, and rotation. This persistent discharge was related to nerve or capsular injury with the consequent release of inflammatory mediators, which could stimulate signaling pathways of pain in the spinal cord by central sensitization [156, 157]. 


\subsection{Disc pain}

Degenerative spinal disease is the condition most frequently associated with chronic LBP, particularly in older adults. As a definition, degenerative spinal disease includes DDD and degenerative facet disease or facet OA [158]. A study for the purpose analyze and compare the radiographic severity of DDD and facet degeneration of the lumbosacral spine in adult subjects with and without chronic LBP showed no association between them. This was despite the fact that the highest radiographic severity scores were associated with the presence of pain [159]. Usually, DD may result in radicular pain secondary to stenosis and nerve-root or cauda equina irritation, and discogenic pain derived from disc lesion [160].

Animal studies of healthy IDs have demonstrated the presence of mechanoreceptors in the outer portion of the annulus fibrosus. These nerve fibers correspond to small myelinated (group-III or A-delta fibers) and unmyelinated (group-IV or C fibers) fibers [161, 162, 163]. These fibers are classified into those containing neuropeptides, which express substance $P$ and calcitonin gene-related peptides [164], and nociceptors fibers related to inflammatory pain. These fibers are also dependent on nerve growth factor and have high affinity with the tyrosine kinase A (TrkA) receptor [165]. Discal nerve fibers generally exhibit afferent axons, and cell bodies are located in the dorsal root ganglia [166].

\section{System grading in DD and facet joint degeneration}

Currently, MRI is considered as the gold standard in imaging of the spine; however, the diagnosis of facet $\mathrm{OA}$ remains a challenge for clinicians. For this purpose, different methods have been used such as the planar X-ray, CT and MRI scans, dynamic bending films, and planar radionuclide bone scanning [167].

Usually, the degree of DD is determined by macroscopic observation on MRI. Comparatively, facet OA may not be evaluated with precision by MRI as with CT scans [168, 169]. Commonly, conventional radiography (X-ray films) is used in the evaluation of arthritic changes of the spine, although CT shows joints with better resolution [170, 171]. It has been reported that CT can show the axial plane of the facet joint and the osteoarthritic changes with precision [171]. However, MRI provides axial and sagittal images of the facet, which are useful in assessing degenerative spinal joint disease [168]. Several studies have reported accuracy in the evaluation of the facet OA with MRI at the rate of between $93 \%$ and $95 \%$ [85, 172]. So far, it has been accepted that MRI is a useful method in the assessment of OA of the lumbar facet joints.

Different scoring systems have been described in evaluating the disc and facet degeneration. A previous study recommends intraobserver and interobserver reliability tests in the evaluation of lumbar degenerative changes [173]. One of these systems used lateral radiographic projections and was easy to apply [174]. However, one that used MRI showed high feasibility [175]. Comparatively, other systems cannot be applied to patients and have been used to evaluate DD in vitro based on detailed morphological studies [97, 176]. In cervical DD, a system based on lateral radiographs and easy to implement was the only one recommended [177]. 
Regarding grading systems for lumbar facet joint degeneration, recommendations were based solely on CT [170] or CT and MRI systems [178]. Differentially in cervical facet joint degeneration, a system based on lateral radiographs was recommended [177].

Lumbar DD is classified into five grades according to macroscopic characteristics such as fibrosis, mucinous degeneration, erosion of cartilage endplate, and osteophyte formation on sagittal sections [176]. Histologically, lumbar DD on sagittal paraffin sections contains parameters such as cell proliferation, mucinous degeneration, cell death, tear and cleft formation, and disc granular changes. Additional features include disorganization and cracks of cartilage, microfractures, bone neoformation, and endplate sclerosis [97].

Radiographically, a method for assessing the presence and severity of lumbar DD is based on joint space narrowing, anterior and posterior osteophyte formation, and subchondral sclerosis [174]. However, the best accepted grading system is based on the characteristics of the degenerative lumbar disc on MRI, such as the distinction of nucleus and annulus, the signal intensity, and height of ID [175]. Moreover, grading of lumbar facet joint degeneration appreciates the joint space narrowing, sclerosis, hypertrophy, and osteophyte formation on oblique conventional radiographs and CT scans [170] or CT and MRI scans [178].

Categorization of cervical DD is based on plain radiography and includes parameters such as osteophytosis, disc space narrowing, and sclerosis of vertebral plates [177]. Furthermore, grading of cervical facet joint degeneration on lateral radiographs determines the presence of osteophytes on the articular margins of facets of apophyseal joints and sclerosis [177].

Additionally, radionuclide bone scintigraphy with single photon emission CT (SPECT) has been used to detect microcalcification due to increased osteoblastic activity [179, 180]. More recently, it was reported that the hybrid SPECT/CT imaging identifies potential chronic spinal pain generators in $92 \%$ of cervical spine scans and $86 \%$ of lumbar spine scans [181].

Figures 2 and 3 show the MRI results of patients with cervical and lumbar OA.

\section{Inflammatory cytokines and degenerative lumbar spinal disease}

It is known that $\mathrm{OA}$ is associated with facet joint pain. The generation mechanisms of pain could be due to mechanical stress and joint instability or misalignment that often accompany $\mathrm{DD}$ and aging. In this regard, the presence of inflammatory mediators such as prostaglandins in facet joints of patients with lumbar spinal degenerative disorders were found [182]. These findings suggest that chemical factors besides mechanical factors arising from the facet joint could be related to pain in OA [183, 184, 185].

Another study demonstrated increase in the concentration of IL-6 in the synovium and cartilage of the facet joint by CLEIA method (Chemiluminescent Enzyme Immunoassay). The tissues analyzed in this study were obtained from patients with disc herniation and lumbar spinal stenosis [186]. The role of IL-6 in the spinal joint disease is controversial; it can facilitate the inflammation together with IL- $1 \beta$ and TNF- $\alpha$ in the early stages of the immune reaction, 
or may be involved in autoimmune states producing antibodies or act as an anti-inflammatory cytokine. According to these assertions, the authors proposed that IL-6 induces continuous local inflammation caused by mechanical stress on the facet joint [186]. Similarly, a significant increase was detected in IL-1 $\beta$ in patients with lumbar spinal canal stenosis than the lumbar herniated disc, which correlated with higher scores on scales of leg pain [187]. More recently, the overexpression of MMP-1 induced by IL-1 $\beta$ was revealed, suggesting an important role in the inflammation associated with lumbar facet joint degeneration [188].

Also were reported inflammatory chemical mediators such as prostaglandins and leukotrienes in facet cartilage and subchondral bone obtained from patients with degenerative lumbar spinal disorders. Here, it was suggested that these chemical mediators may be involved in inflammation and pain generation at the local lumbar facet joints [182].
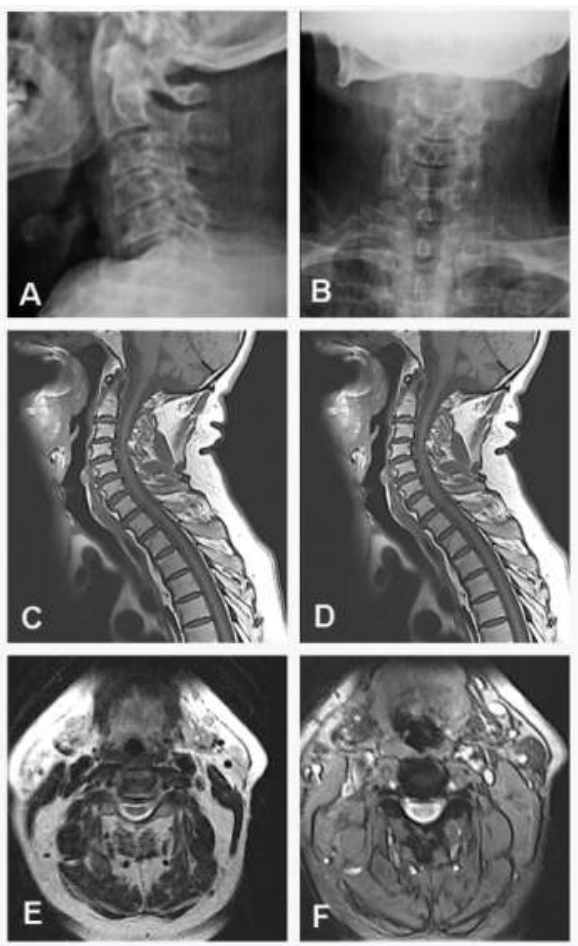

Figure 2. A. Lateral cervical spine radiograph with decreased general bone density; correction of the cervical lordosis; vertebral platforms sclerosis; decrease in intervertebral spaces at C3-C4, C4-C5, and C5-C6; syndesmophytes; reduction in diameter of intervertebral foramina at C2-C3, C3-C4, and C4-C5; decreased facet interface at C2-C3, C3-C4, and C4-C5; and spondylolisthesis at C4-C5. B. Anterior-posterior cervical spine radiograph with loss facet interface at C2-C3, C3-C4, and C4-C5; decreased vertebral space at C2-C3, C3-C4, and C4-C5. C. Sagittal MRI of cervical spine at stage T1 with vertebral platforms sclerosis, osteophyte formation, decreased height of IDs, and disc extrusion mainly in the intervertebral spaces at C4 and at C3-C4-C5. D. Sagittal MRI in T2 phase with decrease caliber medullary canal by the presence of posterior osteophytes, hypertrophy of posterior longitudinal ligament, and ID extrusion. E-F. MRI axial slices in T2 phase with reduced caliber of the cervical canal and compression of the spinal cord. 

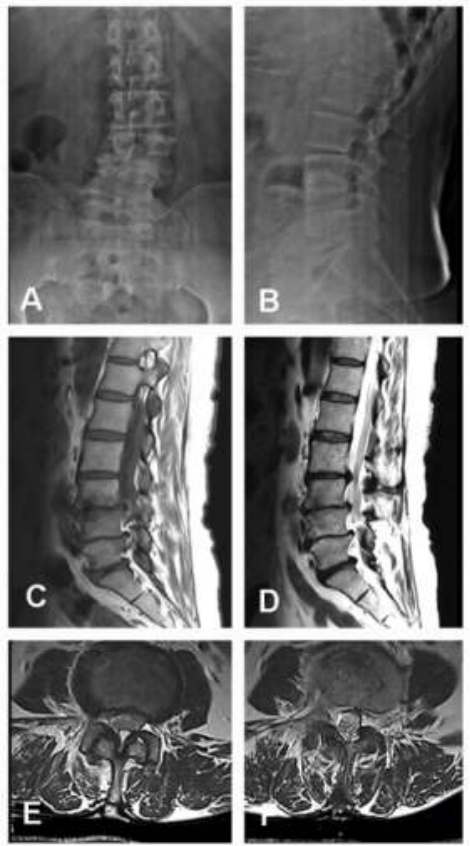

Figure 3. A. Antero-posterior radiograph with left lumbar scoliosis, plastic deformation of the last three lumbar vertebrae, vertebral platforms sclerosis, osteophytes, and decreased height of intervertebral spaces. B. Lateral radiograph of lumbar spine with spinal platform sclerosis, osteophytes, and reduced height of the L3-L4, L4-L5, and L5-S1 IDs. C. Sagittal MRI of lumbar spine in T1 phase with sclerosis of the vertebral platforms, Modic changes, osteophytes, decreased height of IDs, and disc protrusion at L3-L4, L4-L5, and L5-S1 with narrow lumbar canal. D. Sagittal MRI of lumbar spine in T2 phase with vertebral platform sclerosis; osteophytes; decreased height of IDs; disc protrusion at L3L4, L4-L5, and L5-S1 with lumbar canal narrowing; decreased spaces at L3-L4 and L4-L5; and bulging of IDs at L2-L3 and L5-S1. E-F. MRI axial slices of lumbar spine facet degenerative changes and hypertrophy of the ligamentum flavum and lumbar stenosis at different levels.

\section{Angiogenesis, calcification, and programmed cell death in DD}

As described above, degenerative changes of the ID involve processes such as neovascularization, calcification, and cell death. Angiogenesis has been described in degenerated and herniated discs [189]. A degenerative disc is defined as a disc protruding into the spinal canal or neural foramens resulting in compression of the nerve roots [189]. The herniated nucleus pulposus develops fibrotic and angiogenic reactions [190, 191]. This process involves factors such as TGF- $\beta$, TNF- $\alpha$, VEGF, MMP-1, and MMP-3 [191, 192].

Similarly, the intradiscal calcification has been significantly correlated with DD [193]. Disc calcification occurs in the annulus, fibrocartilaginous plate, and nucleus pulposus that appears as amorphous deposits of calcium salts [194] asymptomatic in most cases. The frequency of degenerative disc calcification varies from $3.1 \%$ to $65 \%$ as assessed by microscopy and MRI 
$[195,196,197]$. Another study reported that microscopic calcification was significantly higher in degenerative discs than in those obtained from normal cadavers ( $54.4 \%$ vs. $6.7 \%)$, and it is also higher in Modic type III than in type I ( $95.0 \%$ and $13.0 \%$, respectively). The same study also refers angiogenesis in degenerative discs (41.0\%) and in calcified discs (59.2\%) [198].

The etiology of disc calcification remains uncertain. Two possible mechanisms of calcification disc have been proposed: one in which inflammatory cytokines such as VEGF and MMPs released into the degenerative disc promote expression of osteopontin, induce differentiation of osteoprogenitor cells, and allow calcification; and the other through indirect mechanisms in which these molecular mediators promote angiogenesis, and this, in turn, stimulates macrophage infiltration, the formation of new osteoprogenitor cells, and finally the progressive calcification [198].

As we have mentioned in this review, in addition to mechanical and genetic factors, apoptotic cell death is another event type that contributes to the development of disc degeneration (DD) $[74,132,134,199,200,201,202,203]$. Apoptosis in degenerative discs is described as that occurring through activation of the mitochondrial [74], death receptor [204], and the endoplasmic reticulum pathway $[205,206]$.

The static axial compressive load [74, 108, 134], the static bending compressive load [133], the dynamic axial compressive load [65, 207], and the imbalance of dynamic and/or static forces of the spine [199] have been considered in programmed cell death (PCD) on degenerative disc. Load effects increase lactate concentration, decline oxygen tension, decrease nutrient level, reduces tissue permeability and secondarily the water content [208, 209]. Biomechanical stimuli such as serum deprivation [210], nitric oxide [201], lipid peroxidation [132], hypoxiainducible factor- $1 \alpha$ [211], and even normal oxygen concentrations [212] have also been involved in the induction and increase of PCD.

The death of disc cells has been reported to be significant as age increases [97]. Elsewhere in the body, it is well established that apoptotic cells are removed by phagocytosis; however, macrophages or phagocytes are not cells that are normally present on the disc. In vitro studies have shown that nucleus pulposus cells are able to perform, as well as competent phagocytes and stimulate phagocytosis [213].

\section{Conclusion}

Spinal OA is a condition characterized by failure in motion segments, usually as a result of exposure to heavy physical load and aging. By definition, this disease induces degenerative changes in the facet joints and the IDs. One of the predominant symptoms of spinal OA is neck pain and LBP syndrome, which involves prolonged disability and high care costs. However there is controversy whether the prevalence, severity, and imaging findings are related to the pain sensation. The fields of molecular biology and mechanobiology of the degenerative process also require research to understand the pathophysiological mechanisms that lead to it and, thus, be able to contribute in the development of regenerative medicine and technological innovation with the improvement of prototypes for design of orthopedic components. 


\section{Acknowledgements}

We thank M.D. Eulalio Elizalde Martínez, Chief of Orthopaedic Spine Surgery; M.D. Armando Fabio Ramos Guerrero, Spine Surgery Training of Hospital "Dr. Victorio de la Fuente Narváez", IMSS, Distrito Federal, Mexico; and M.D. Misael Vargas López of the Escuela Nacional de Medicina y Homeopatía-IPN for their valuable support in the preparation of this chapter. This work was supported by the SIP 20141449 project.

\section{Author details}

Elizabeth Pérez-Hernández ${ }^{1 *}$, Nury Pérez-Hernández ${ }^{2}$ and Ariel Fuerte-Hernández ${ }^{3}$

*Address all correspondence to: perezheliza@aol.com

1 División de Educación e Investigación en Salud, UMAE “Dr. Victorio de la Fuente Narváez”, Hospital de Ortopedia, Instituto Mexicano del Seguro Social, Distrito Federal, México

2 Escuela Nacional de Medicina y Homeopatía, Instituto Politécnico Nacional, Distrito Federal, México

3 Escuela Superior de Ingeniería Mecánica y Eléctrica, Instituto Politécnico Nacional, Distrito Federal, México

\section{References}

[1] Guccione AA, Felson DT, Anderson JJ, Anthony JM, Zhang Y, Wilson PW, et al. The effects of specific medical conditions on the functional limitations of elders in the Framingham Study. Am J Public Health. 1994; 84(3): 351-8.

[2] Lawrence RC, Felson DT, Helmick CG, Arnold LM, Choi H, Deyo RA, et al. Estimates of the prevalence of arthritis and other rheumatic conditions in the United States. Part II. Arthritis Rheum. 2008; 58(1): 26-35.

[3] Battié MC, Videman T, Parent E. Lumbar disc degeneration: epidemiology and genetic influences. Spine. 2004; 29(23): 2679-90. Review.

[4] Ethgen O, Bruyere O, Richy F, Dardennes C, Reginster JY. Health-related quality of life in total hip and total knee arthroplasty. A qualitative and systematic review of the literature. J Bone Joint Surg Am. 2004; 86-A(5): 963-74.

[5] Bitton R. The economic burden of osteoarthritis. Am J Manag Care. 2009; 15(8 Suppl): S230-5. 
[6] Borenstein D. Does osteoarthritis of the lumbar spine cause chronic low back pain? Curr Rheumatol Rep. 2004; 6(1): 14-9.

[7] Rubin DI. Epidemiology and risk factors for spine pain. Neurol Clin. 2007; 25(2): 353-71.

[8] Katz JN. Lumbar disc disorders and low back pain: socioeconomic factors and consequences. J Bone Joint Surg Am. 2006; 88(Suppl 2): 21-4.

[9] Ricci JA, Stewart WF, Chee E, Leotta C, Foley K, Hochberg MC. Back pain exacerbations and lost productive time costs in United States workers. Spine. 2006; 31(26): 3052-60.

[10] Stewart WF, Ricci JA, Chee E, Morganstein D, Lipton R. Lost productive time and cost due to common pain conditions in the US workforce. Jama. 2003; 290(18): 2443-54.

[11] Muraki S, Akune T, Oka H, Ishimoto Y, Nagata K, Yoshida M, et al. Incidence and risk factors for radiographic lumbar spondylosis and lower back pain in Japanese men and women: the ROAD study. Osteoarthritis and cartilage. 2012; 20(7): 712-8.

[12] Goode AP1, Marshall SW, Renner JB, Carey TS, Kraus VB, Irwin DE, et al. Lumbar spine radiographic features and demographic, clinical, and radiographic knee, hip and hand osteoarthritis. Arthritis Care Res (Hoboken). 2012; 64(10): 1536-44.

[13] Gellhorn AC, Katz JN, Suri P. Osteoarthritis of the spine: the facet joints. Nat Rev Rheumatol. 2013; 9(4): 216-24.

[14] Pal GP, Routal RV, Saggu SK. The Orientation of the Articular Facets of the Zygapophyseal Joints at the Cervical and Upper Thoracic Region. J Anat. 2001; 198(4): 431-41.

[15] Pal GP, Routal RV. Mechanism of Change in the Orientation of the Articular Process of the Zygapophyseal Joint at the Thoracolumbar Junction. J Anat. 1999; 195(2): 199-209.

[16] Panjabi MM, Crisco JJ, Vasavada A, Oda T, Cholewicki J, Nibu K, et al. Mechanical Properties of the Human Cervical Spine as Shown by Three-Dimensional Load-Displacement Curves. Spine. 2001; 26(24): 2692-700.

[17] Kozanek M, Wang S, Passias PG, Xia Q, Li G, Bono CM, et al. Range of Motion and Orientation of the Lumbar Facet Joints in Vivo. Spine. 2009; 34(19): E689-96.

[18] Panjabi MM, Oxland T, Takata K, Goel V, Duranceau J, Krag M. Articular Facets of the Human Spine. Quantitative Three-Dimensional Anatomy. Spine. 1993; 18(10): 1298-310.

[19] Yoganandan N, Knowles SA, Maiman DJ, Pintar FA. Anatomic Study of the Morphology of Human Cervical Facet Joint. Spine. 2003; 28(20): 2317-23. 
[20] Varlotta GP, Lefkowitz TR, Schweitzer M, Errico TJ, Spivak J, Bendo JA, et al. The Lumbar Facet Joint: a Review of Current Knowledge: Part 1: Anatomy, Biomechanics, and Grading. Skeletal Radiol. 2011; 40(1): 13-23.

[21] Womack W, Woldtvedt D, Puttlitz CM. Lower Cervical Spine Facet Cartilage Thickness Mapping. Osteoarthritis Cartilage. 2008; 16(9): 1018-23.

[22] Armstrong CG, Mow VC. Variations in the Intrinsic Mechanical Properties of Human Articular Cartilage with Age, Degeneration, and Water Content. J Bone Joint Surg Am. 1982; 64(1): 88-94.

[23] Adams MA, Dolan P, McNally DS. The Internal Mechanical Functioning of Intervertebral Discs and Articular Cartilage, and its Relevance to Matrix Biology. Matrix Biol. 2009; 28(7): 384-9.

[24] Eckstein F, Milz S, Anetzberger H, Putz R. Thickness of the subchondral mineralised tissue zone (SMZ) in normal male and female and pathological human patellae. J Anat 1998; 192(Pt 1): 81-90.

[25] Duan CY, Espinoza Orías AA, Shott S, An HS, Andersson GB, Hu JZ, et al. In vivo measurement of the subchondral bone thickness of lumbar facet joint using magnetic resonance imaging. Osteoarthritis Cartilage. 2011; 19(1): 96-102.

[26] Iwanaga T, Shikichi M, Kitamura H, Yanase H, Nozawa-Inoue K. Morphology and Functional Roles of Synoviocytes in the Joint. Arch Histol Cytol. 2000; 63(1): 17-31.

[27] Bogduk N, Engel R. The Menisci of the Lumbar Zygapophyseal Joints. A Review of Their Anatomy and Clinical Significance. Spine. 1984; 9(5): 454-60.

[28] Friedrich KM, Reiter G, Pretterklieber ML, Pinker K, Friedrich M, Trattnig S, et al. Reference Data for in Vivo Magnetic Resonance Imaging Properties of Meniscoids in the Cervical Zygapophyseal Joints. Spine. 2008; 33(21): E778-E83.

[29] Taylor JR, McCormick CC. Lumbar Facet Joint Fat Pads: Their Normal Anatomy and Their Appearance when Enlarged. Neuroradiology. 1991; 33(1): 38-42.

[30] Yahia LH, Garzon S. Structure on the Capsular Ligaments of the Facet Joints. Ann Anat. 1993; 175(2): 185-8.

[31] Yamashita T, Minaki Y, Ozaktay AC, Cavanaugh JM, King AI. A Morphological Study of the Fibrous Capsule of the Human Lumbar Facet Joint. Spine. 1996; 21(5): $538-43$.

[32] Roberts S, Evans H, Trivedi J, Menage J. Histology and pathology of the human intervertebral disc. J Bone Joint Surg Am. 2006 Apr; 88(Suppl 2): 10-4. Review.

[33] Schollmeier G, Lahr-Eigen R, Lewandrowski KU. Observations on fiber-forming collagens in the anulus fibrosus. Spine. 2000; 25(21): 2736-41. 
[34] Marchand F, Ahmed AM. Investigation of the laminate structure of lumbar disc anulus fibrosus. Spine. 1990; 15(5): 402-10.

[35] Chelberg MK, Banks GM, Geiger DF, Oegema TR Jr. Identification of heterogeneous cell populations in normal human intervertebral disc. J Anat. 1995 Feb; 186(Pt 1): 43-53.

[36] Yu J, Fairbank JC, Roberts S, Urban JP. The elastic fibre network of the annulus fibrosus of the normal and scoliotic human intervertebral disc. Spine. 2005; 30(16): 1815-20.

[37] Gruber HE, Hanley EN Jr. Ultrastructure of the human intervertebral disc during aging and degeneration: comparison of surgical and control specimens. Spine. 2002; 27(8): 798-805.

[38] Roberts S, Menage J, Duance V, Wotton S, Ayad S. Collagen types around the cells of the intervertebral disc and cartilage end plate: an immunolocalization study. Spine. 1991; 16(9): 1030-8.

[39] Roberts S, Menage J, Duance V, Wotton SF. Type III collagen in the intervertebral disc. Histochem J. 1991a; 23(11-12): 503-8.

[40] Roberts S, Ayad S, Menage PJ. Immunolocalisation of type VI collagen in the intervertebral disc. Ann Rheum Dis. 1991b; 50(11): 787-91.

[41] Feng H, Danfelter M, Strömqvist B, Heinegård D. Extracellular matrix in disc degeneration. J Bone Joint Surg Am. 2006; 88(Suppl 2): 25-9. Review.

[42] Heinegård D, Aspberg A, Franzén A, Lorenzo P. Glycosylated matrix proteins. In: Royce PM, Steinmann B, editors. Connective tissue and its heritable disorders: molecular, genetic, and medical aspects. $2^{\text {nd }}$ ed. New York: Wiley-Liss. 2003; 271-91.

[43] Roberts S. Disc morphology in health and disease. Biochem Soc Trans. 2002; 30(Pt 6): 864-9. Review.

[44] Aigner T, Gresk-otter KR, Fairbank JC, von der Mark K, Urban JP. Variation with age in the pattern of type $X$ collagen expression in normal and scoliotic human intervertebral discs. Calcif Tissue Int. 1998; 63(3): 263-8.

[45] Holm S, Maroudas A, Urban JP, Selstam G, Nachemson A. Nutrition of the intervertebral disc: solute transport and metabolism. Connect Tissue Res. 1981; 8(2): 101-19.

[46] Ishihara H, Urban JP. Effects of low oxygen concentrations and metabolic inhibitors on proteoglycan and protein synthesis rates in the intervertebral disc. J Orthop Res. 1999; 17(6): 829-35.

[47] Bibby SR, Jones DA, Ripley RM, Urban JP. Metabolism of the intervertebral disc: effects of low levels of oxygen, glucose, and $\mathrm{pH}$ on rates of energy metabolism of bovine nucleus pulposus cells. Spine. 2005; 30(5): 487-96. 
[48] Ohshima H, Urban JP. The effect of lactate and $\mathrm{pH}$ on proteoglycan and protein synthesis rates in the intervertebral disc. Spine. 1992; 17(9): 1079-82.

[49] Razaq S, Wilkins RJ, Urban JP. The effect of extracellular $\mathrm{pH}$ on matrix turnover by cells of the bovine nucleus pulposus. Eur Spine J. 2003; 12(4): 341-9.

[50] Windhaber RA, Wilkins RJ, Meredith D. Functional characterisation of glucose transport in bovine articular chondrocytes. Pflugers Arch. 2003; 446(5): 572-7.

[51] Bibby SR, Urban JP. Effect of nutrient deprivation on the viability of intervertebral disc cells. Eur Spine J. 2004; 13(8): 695-701.

[52] Horner HA, Urban JP. 2001 Volvo Award Winner in Basic Science Studies: Effect of nutrient supply on the viability of cells from the nucleus pulposus of the intervertebral disc. Spine. 2001; 26(23): 2543-9.

[53] Crock HV, Goldwasser M, Yoshizawa H. Vascular anatomy related to the intervertebral disc. In: Ghosh P, editor. Biology of the intervertebral disc. Boca Raton, FL: CRC Press. 1991; 109-33.

[54] Crock HV, Yoshizawa H. The blood supply of the lumbar vertebral column. Clin Orthop Relat Res. 1976; (115): 6-21.

[55] Roberts S, Menage J, Urban JP. Biochemical and structural properties of the cartilage end-plate and its relation to the intervertebral disc. Spine. 1989; 14(2): 166-74.

[56] Setton LA, Zhu W, Weidenbaum M, Ratcliffe A, Mow VC. Compressive properties of the cartilaginous end-plate of the baboon lumbar spine. J Orthop Res. 1993; 11(2): 228-39.

[57] Urban JP, Holm S, Maroudas A, Nachemson A. Nutrition of the intervertebral disc: effect of fluid flow on solute transport. Clin Orthop Relat Res. 1982; (170): 296-302.

[58] Katz MM, Hargens AR, Garfin SR. Intervertebral disc nutrition. Diffusion versus convection. Clin Orthop Relat Res. 1986; 210: 243-5.

[59] Ferguson SJ, Ito K, Nolte LP. Fluid flow and convective transport of solutes within the intervertebral disc. J Biomech. 2004; 37(2): 213-21.

[60] Mokhbi Soukane D, Shirazi-Adl A, Urban JPG. Nonlinear coupled diffusion of glucose, oxygen and lactic acid in the intervertebral disc. Presented as a poster exhibit at the $52^{\text {th }}$ Annual Meeting of the Orthopaedic Research Society; Chicago, IL. 2006 March 19-22.

[61] Boubriak OA, Lee RB, Urban JPG. Nutrient supply to cells of the intervertebral disc: effect of diurnal hydration changes. Presented as a poster exhibit at the $49^{\text {th }}$ Annual Meeting of the Orthopaedic Research Society. New Orleans, LA. 2003 February 2-5. 
[62] Ohshima H, Urban JP, Bergel DH. Effect of static load on matrix synthesis rates in the intervertebral disc measured in vitro by a new perfusion technique. J Orthop Res. 1995; 13(1): 22-9.

[63] Chen J, Yan W, Setton LA. Static compression induces zonal-specific changes in gene expression for extracellular matrix and cytoskeletal proteins in intervertebral disc cells in vitro. Matrix Biol. 2004; 22(7): 573-83.

[64] Maclean JJ, Lee CR, Alini M, Iatridis JC. Anabolic and catabolic mRNA levels of the intervertebral disc vary with the magnitude and frequency of in vivo dynamic compression. J Orthop Res. 2004; 22(6): 1193-200.

[65] Walsh AJ, Lotz JC. Biological response of the intervertebral disc to dynamic loading. J Biomech. 2004; 37(3): 329-37.

[66] Handa T, Ishihara H, Ohshima H, Osada R, Tsuji H, Obata K. Effects of hydrostatic pressure on matrix synthesis and matrix metalloproteinase production in the human lumbar intervertebral disc. Spine. 1997; 22(10): 1085-91.

[67] Hutton WC, Elmer WA, Boden SD, Hyon S, Toribatake Y, Tomita K, et al. The effect of hydrostatic pressure on intervertebral disc metabolism. Spine. 1999; 24(15): 1507-15.

[68] Ishihara H, McNally DS, Urban JP, Hall AC. Effects of hydrostatic pressure on matrix synthesis in different regions of the intervertebral disk. J Appl Physiol. 1996; 80(3): 839-46.

[69] Liu GZ, Ishihara H, Osada R, Kimura T, Tsuji H. Nitric oxide mediates the change of proteoglycan synthesis in the human lumbar intervertebral disc in response to hydrostatic pressure. Spine. 2001; 26(2): 134-41.

[70] Urban JP. The role of the physicochemical environment in determining disc cell behaviour. Biochem Soc Trans. 2002; 30(Pt 6): 858-64.

[71] Ishihara H, Warensjo K, Roberts S, Urban JP. Proteoglycan synthesis in the intervertebral disk nucleus: the role of extracellular osmolality. Am J Physiol. 1997; 272: C1499-506.

[72] Pritchard S, Erickson GR, Guilak F. Hyperosmotically induced volume change and calcium signaling in intervertebral disk cells: the role of the actin cytoskeleton. Biophys J. 2002; 83(5): 2502-10.

[73] Rannou F, Richette P, Benallaoua M, Francois M, Genries V, Korwin-Zmijowska C, et al. Cyclic tensile stretch modulates proteoglycan production by intervertebral disc annulus fibrosus cells through production of nitrite oxide. J Cell Biochem. 2003; 90(1): $148-57$. 
[74] Rannou F, Lee TS, Zhou RH, Chin J, Lotz JC, Mayoux-Benhamou MA, et al. Intervertebral disc degeneration: the role of the mitochondrial pathway in annulus fibrosus cell apoptosis induced by overload. Am J Pathol. 2004; 164(3): 915-24.

[75] Brodke DS, Ritter SM. Nonoperative management of low back pain and lumbar disc degeneration. Instr Course Lect. 2005; 54: 279-86.

[76] Bressler HB, Keyes WJ, Rochon PA, Badley E. The prevalence of low back pain in the elderly: a systematic review of the literature. Spine. 1999; 24(17): 1813-9.

[77] Mooney V, Robertson J. The facet syndrome. Clin Orthop Relat Res.1976; 115: 149-56.

[78] Eisenstein SM, Parry CR. The lumbar facet arthrosis syndrome. J Bone Joint Surg Br. 1987; 69(1): 3-7.

[79] Eubanks JD, Lee MJ, Cassinelli E, Ahn NU. Prevalence of lumbar facet arthrosis and its relationship to age, sex, and race: an anatomic study of cadaveric specimens. Spine. 2007; 32(19): 2058-62.

[80] Master DL, Toy JO, Eubanks JD, Ahn NU. Cervical endplate and facet arthrosis: an anatomic study of cadaveric specimens. J Spinal Disord Tech. 2012; 25(7): 379-82.

[81] Mikkelsen W, Duff I. Age-sex specific prevalence of radiographic abnormalities of the joints of the hands, wrists and cervical spine of adult residents of the Tecumseh, Michigan, Community Health Study area, 1962-1965. J Chronic Dis. 1970; 23(3): 151-9.

[82] Suri P, Miyakoshi A, Hunter DJ, Jarvik JG, Rainville J, Guermazi A, et al. Does lumbar spinal degeneration begin with the anterior structures? A study of the observed epidemiology in a community-based population. BMC Musculoskelet. Disord. 2011; 12: 202.

[83] Bernard TE, Wilder FV, Aluoch M, Leaverton PE. Job-related osteoarthritis of the knee, foot, hand, and cervical spine. J Occup Environ Med. 2010; 52(1): 33-8.

[84] Kalichman L, Li L, Kim DH, Guermazi A, Berkin V, O'Donnell CJ, et al. Facet joint osteoarthrosis and low back pain in the community-based population. Spine. 2008; 33(23): 2560-5.

[85] Fujiwara A, Tamai K, Yamato M, An HS, Yoshida H, Saotome K, et al. The relationship between facet joint osteoarthritis and disc degeneration of the lumbar spine: an MRI study. Eur Spine J. 1999; 8(5): 396-401.

[86] Abbas J, Hamoud K, Masharawi YM, May H, Hay O, Medlej B, et al. Ligamentum flavum thickness in normal and stenotic lumbar spines. Spine. 2010; 35(12): 1225-30.

[87] Kirkaldy-Willis WH, McIvor GW. Spinal stenosis. Clin Orthop Relat Res. 1976; (115): 2-144. 
[88] Tischer T, Aktas T, Milz S, Putz R. Detailed pathological changes of human lumbar facet joints L1-L5 in elderly individuals. Eur Spine J. 2006; 15(3): 308-15.

[89] Kalichman L, Suri P, Guermazi A, Li L, Hunter DJ. Facet orientation and tropism: associations with facet joint osteoarthritis and degeneratives. Spine. 2009; 34(16): E579-85.

[90] Fujiwara A, Tamai K, An HS, Lim TH, Yoshida H, Kurihashi A, et al. Orientation and osteoarthritis of the lumbar facet joint. Clin Orthop Relat Res. 2001; 385: 88-94.

[91] Masharawi Y, Rothschild B, Dar G, Peleg S, Robinson D, Been E, et al. Facet orientation in the thoracolumbar spine: three-dimensional anatomic and biomechanical analysis. Spine 2004; 29(16): 1755-63.

[92] Abbas J, Hamoud K, Peleg S, May H, Masharawi Y, Cohen H, Peled N, Hershkovitz I. Facet joints arthrosis in normal and stenotic lumbar spines. Spine. 2011; 36(24): E1541-6.

[93] Kalichman L, Hodges P, Li L, Guermazi A, Hunter DJ. Changes in paraspinal muscles and their association with low back pain and spinal degeneration: CT study. Eur Spine J. 2010; 19(7): 1136-44.

[94] Battié MC, Videman T. Lumbar disc degeneration: epidemiology and genetics. J Bone Joint Surg Am. 2006; 88(Suppl 2): 3-9. Review.

[95] Videman T, Battié MC, Gill K, Manninen H, Gibbons LE, Fisher LD. Magnetic resonance imaging findings and their relationships in the thoracic and lumbar spine. Insights into the etiopathogenesis of spinal degeneration. Spine. 1995; 20(8): 928-35.

[96] Beneke R. Zur Lehre von der Spondylitis deformans. Versammlung deutscher Naturforscher und Arzte. Braunschweig. 1897.

[97] Boos N, Weissbach S, Rohrbach H, Weiler C, Spratt KF, Nerlich AG. Classification of age-related changes in lumbar intervertebral discs: 2002 Volvo Award in basic science. Spine. 2002; 27(23): 2631-44.

[98] Videman T, Nurminen M. The occurrence of anular tears and their relation to lifetime back pain history: a cadaveric study using barium sulfate discography. Spine. 2004; 29(3): 2668-76.

[99] Battié MC, Videman T, Gibbons LE, Fisher LD, Manninen H, Gill K. Determinants of lumbar disc degeneration. A study relating lifetime exposures and magnetic resonance imaging findings in identical twins. Spine. 1995; 20(24): 2601-12.

[100] Miller JA, Schmatz C, Schultz AB. Lumbar disc degeneration: correlation with age, sex, and spine level in 600 autopsy specimens. Spine. 1988; 13(2): 173-8.

[101] Battié MC, Haynor DR, Fisher LD, Gill K, Gibbons LE, Videman T. Similarities in degenerative findings on magnetic resonance images of the lumbar spines of identical twins. J Bone Joint Surg Am. 1995a; 77(11): 1662-70. 
[102] Sambrook PN, MacGregor AJ, Spector TD. Genetic influences on cervical and lumbar disc degeneration: a magnetic resonance imaging study in twins. Arthritis Rheum. 1999; 42(2): 366-72.

[103] Videman T, Leppävuori J, Kaprio J, Battié MC, Gibbons LE, Peltonen L, et al. Intragenic polymorphisms of the vitamin $\mathrm{D}$ receptor gene associated with intervertebral disc degeneration. Spine. 1998; 23(23): 2477-85.

[104] Solovieva S, Lohiniva J, Leino-Arjas P, Raininko R, Luoma K, Ala-Kokko L, et al. COL9A3 gene polymorphism and obesity in intervertebral disc degeneration of the lumbar spine: evidence of gene-environment interaction. Spine. 2002; 27(23): 2691-6.

[105] Liu YK, Njus G, Buckwalter J, Wakano K. Fatigue response of lumbar intervertebral joints under axial cyclic loading. Spine. 1983; 8(8): 857-65.

[106] Gilbertson LG, Goel VK, Kong WZ, Clausen JD. Finite element methods in spine biomechanics research. Crit Rev Biomed Eng. 1995; 23(5-6): 411-73.

[107] Natarajan RN, Williams JR, Andersson GB. Modeling changes in intervertebral disc mechanics with degeneration. J Bone Joint Surg Am. 2006; 88(Suppl 2): 36-40. Review.

[108] Lotz JC, Colliou OK, Chin JR, Duncan NA, Liebenberg E. Compression-induced degeneration of the intervertebral disc: an in vivo mouse model and finite-element study. Spine. 1998; 23(23): 2493-506.

[109] Simon BR, Wu JS, Carlton MW, Evans JH, Kazarian LE. Structural models for human spinal motion segments based on a poroelastic view of the intervertebral disk. J Biomech Eng. 1985; 107(4): 327-35.

[110] Riches PE, Dhillon N, Lotz J, Woods AW, McNally DS. The internal mechanics of the intervertebral disc under cyclic loading. J Biomech. 2002; 35(9): 1263-71.

[111] Laible JP, Pflaster DS, Krag MH, Simon BR, Haugh LD. A poroelastic-swelling finite element model with application to the intervertebral disc. Spine. 1993; 18(5): 659-70.

[112] Selard E, Shirazi-Adl A, Urban JP. Finite element study of nutrient diffusion in the human intervertebral disc. Spine. 2003; 28(17): 1945-53.

[113] Natarajan RN, Williams JR, Andersson GB. Recent advances in analytical modeling of lumbar disc degeneration. Spine. 2004; 29(23): 2733-41.

[114] Adams MA, Roughley PJ. What is intervertebral disc degeneration, and what causes it? Spine. 2006; 31(18): 2151-61.

[115] Le Maitre CL, Freemont AJ, Hoyland JA. Accelerated cellular senescence in degenerate intervertebral discs: a possible role in the pathogenesis of intervertebral disc degeneration. Arthritis Res Ther. 2007; 9(3): R45. 
[116] Benoist M. Natural history of the aging spine. Eur Spine J. 2003; 12(Suppl 2): S86-9. Review.

[117] Pazzaglia UE, Salisbury JR, Byers PD. Development and involution of the notochord in the human spine. J R Soc Med. 1989; 82(7): 413-5.

[118] Wolfe HJ, Putschar WG, Vickery AL. Role of the Notochord in human intervetebral disk. I. Fetus and infant. Clin Orthop Relat Res. 1965; 39: 205-12.

[119] Kim KW, Lim TH, Kim JG, Jeong ST, Masuda K, An HS. The origin of chondrocytes in the nucleus pulposus and histologic findings associated with the transition of a notochordal nucleus pulposus to a fibrocartilaginous nucleus pulposus in intact rabbit intervertebral discs. Spine. 2003; 28(10): 982-90.

[120] Kim KW, Kim YS, Ha KY, Woo YK, Park JB, Park WS, et al. An autocrine or paracrine Fas-mediated counterattack: a potential mechanism for apoptosis of notochordal cells in intact rat nucleus pulposus. Spine. 2005; 30(11): 1247-51.

[121] Cappello R, Bird JL, Pfeiffer D, Bayliss MT, Dudhia J. Notochordal cell produce and assemble extracellular matrix in a distinct manner, which may be responsible for the maintenance of healthy nucleus pulposus. Spine. 2006; 31(8): 873-82.

[122] Ishii T, Tsuji H, Sano A, Katoh Y, Matsui H, Terahata N. Histochemical and ultrastructural observations on brown degeneration of human intervertebral disc. J Orthop Res. 1991; 9(1): 78-90.

[123] Hastreiter D, Ozuna RM, Spector M. Regional variations in certain cellular characteristics in human lumbar intervertebral discs, including the presence of a-smooth muscle actin. J Orthop Res. 2001; 19(4): 597-604.

[124] Le Maitre CL, Freemont AJ, Hoyland JA. The role of interleukin-1 in the pathogenesis of human intervertebral disc degeneration. Arthritis Res Ther. 2005; 7(4): R732-45.

[125] Weiler C, Nerlich AG, Bachmeier BE, Boos N. Expression and distribution of tumor necrosis factor alpha in human lumbar intervertebral discs: a study in surgical specimen and autopsy controls. Spine. 2005; 30(1): 44-54.

[126] Roberts S, Caterson B, Menage J, Evans EH, Jaffray DC, Eisenstein SM. Matrix metalloproteinases and agrecanase: their rôle in disorders of the human intervertebral disc. Spine. 2000; 25(23): 3005-13.

[127] Cs-Szabo G, Ragasa-San Juan D, Turumella V, Masuda K, Thonar EJ, An HS. Changes in mRNA and protein levels of proteoglycans of the anulus fibrosus and nucleus pulposus during intervertebral disc degeneration. Spine. 2002; 27(20): 2212-9.

[128] Rannou F, Corvol M, Revel M, Poiraudeau S. Dégénérescence discale et hernie discale: rôle des métalloprotéases et cytokines. Rev Rhum. 2001; 68(10-11): 913-20.

[129] Roberts S, Johnson E. Innervation du disque intervertebral et lombalgie discale. Rev Rhum. 2000b; 67(Suppl 4): 225-32. 
[130] Weiler C, Nerlich AG, Zipperer J, Bachmeier BE, Boos N. Expression of major matrix metallo proteinases is associated with disc degradation and resorption. Eur Spine J. 2002; 11(4): 308-20.

[131] Bernick S, Cailliet R. Vertebral end-plate changes with aging of human vertebrae. Spine. 1982; 7(2): 97-102.

[132] Ariga K, Yonenobu K, Nakase T, Hosono N, Okuda S, Meng W, et al. Mechanical stress-induced apoptosis of endplate chondrocytes in organ-cultured mouse intervertebral discs: an ex vivo study. Spine. 2003; 28(14): 1528-33.

[133] Court C, Colliou OK, Chin JR, Liebenberg E, Bradford DS, Lotz JC. The effect of static in vivo bending on the murine intervertebral disc. Spine J. 2001; 1(4): 239-45.

[134] Lotz JC, Chin JR. Intervertebral disc cell death is dependent on the magnitude and duration of spinal loading. Spine. 2000; 25(12): 1477-83.

[135] Johnson WE, Eisenstein SM, Roberts S. Cell cluster formation in degenerate lumbar intervertebral discs is associated with increased disc cell proliferation. Connect Tissue Res. 2001; 42(3): 197-207.

[136] Galbusera F, Schmidt H, Neidlinger-Wilke C, Wilke HJ. The effect of degenerative morphological changes of the intervertebral disc on the lumbar spine biomechanics: a poroelastic finite element investigation. Comput Methods Biomech Biomed Engin. 2011; 14(8): 729-39.

[137] Butler D, Trafimow JH, Andersson GB, McNeill TW, Huckman MS. Discs degenerate before facets. Spine. 1990; 15(2): 111-3.

[138] Prescher A. Anatomy and pathology of the aging spine. Eur J Radiol. 1998; 27(3): 181-95.

[139] Kettler A, Werner K, Wilke HJ. Morphological changes of cervical facet joints in elderly individuals. Eur Spine J. 2007; 16(7): 987-92.

[140] Wilke HJ, Zanker D, Wolfram U. Internal morphology of human facet joints: comparing cervical and lumbar spine with regard to age, gender and the vertebral core. J Anat. 2012; 220(3): 233-41.

[141] Oegema TR, Bradford DS. The inter-relationship of facet joint osteoarthritis and degenerative disc disease. Br J Rheumatol. 1991; 30(Suppl 1): 16-20.

[142] Farfan HF. The pathological anatomy of degenerative spondylolisthesis. A cadaver study. Spine. 1980; 5(5): 412-418.

[143] McDougall JJ. Arthritis and pain. Neurogenic origin of joint pain. Arthritis Res Ther. 2006; 8(6): 220. Review.

[144] Schaible HG, Ebersberger A, Von Banchet GS. Mechanisms of pain in arthritis. Ann N Y Acad Sci. 2002; 966: 343-54. 
[145] Yamashita T, Cavanaugh JM, el Bohy AA, Getchell TV, King AI. Mechanosensitive afferent units in the lumbar facet joint. J Bone Joint Surg Am. 1990; 72(6): 865-70.

[146] Yamashita T, Cavanaugh JM, Ozaktay AC, Avramov AI, Getchell TV, King AI. Effect of substance $\mathrm{P}$ on mechanosensitive units of tissues around and in the lumbar facet joint. J Orthop Res. 1993; 11(2): 205-14.

[147] Ozaktay AC, Cavanaugh JM, Blagoev DC, Getchell TV, King AI. Effects of a carrageenan-induced inflammation in rabbit lumbar facet joint capsule and adjacent tissues. Neurosci Res. 1994; 20(4): 355-64.

[148] Beaman DN, Graziano GP, Glover RA, Wojtys EM, Chang V. Substance P innervations of lumbar spine facet joints. Spine. 1993; 18(8): 1044-9.

[149] Manchikanti L, Boswell MV, Singh V, Pampati V, Damron KS, Beyer CD. Prevalence of facet joint pain in chronic spinal pain of cervical, thoracic, and lumbar regions. BMC Musculoskelet Disord. 2004 May 28; 5: 15.

[150] Kallakuri S, Singh A, Chen C, Cavanaugh JM. Demonstration of substance P, calcitonin gene-related peptide, and protein gene product 9.5 containing nerve fibers in human cervical facet joint capsules. Spine. 2004; 29: 1182-6.

[151] Krafft M, Kullgren A, Tingvall C, Bostrom O, Fredriksson R. How crash severity in rear impacts influences short- and long-term consequences to the neck. Accid Anal Prev. 2000; 32(2): 187-95.

[152] Chen C, Lu Y, Cavanaugh JM, Kallakuri S, Patwardhan A. Recording of neural activity from goat cervical facet joint capsule using custom-designed miniature electrodes. Spine. 2005; 30(12): 1367-72.

[153] Lu Y, Chen C, Kallakuri S, Patwardhan A, Cavanaugh JM. Development of an in vivo method to investigate biomechanical and neurophysiological properties of spine facet joint capsules. Eur Spine J. 2005; 14(6): 565-72.

[154] Lu Y, Chen C, Kallakuri S, Patwardhan A, Cavanaugh JM. Neurophysiological and biomechanical characterization of goat cervical facet joint capsules. J Orthop Res. 2005a; 23(4): 779-87.

[155] Lu Y, Chen C, Kallakuri S, Patwardhan A, Cavanaugh JM. Neural response of cervical facet joint capsule to stretch: a study of whiplash pain mechanism. Stapp Car Crash Journal. 2005b; 49: 49-56.

[156] Curatolo M, Petersen-Felix S, Arendt-Nielsen L, Giani C, Zbinden AM, Radanov BP. Central hypersensitivity in chronic pain after whiplash injury. Clin J Pain. 2001; 17(4): 306-15.

[157] Kasch H, Stengaard-Pedersen K, Arendt-Nielsen L, Staehelin Jensen T. Pain thresholds and tenderness in neck and head following acute whiplash injury: a prospective study. Cephalalgia. 2001; 21(3): 189-97. 
[158] Kirkaldy-Willis WH, Farfan HF. Instability of the lumbar spine. Clin Orthop Relat Res. 1982; (165): 110-23.

[159] Hicks GE, Morone N, Weiner DK. Degenerative lumbar disc and facet disease in older adults: prevalence and clinical correlates. Spine. 2009; 34(12): 1301-6.

[160] Lotz JC, Ulrich JA. Innervation, inflammation, and hypermobility may characterize pathologic disc degeneration: review of animal model data. J Bone Joint Surg Am. 2006; 88(Suppl 2): 76-82. Review.

[161] Fagan A, Moore R, Vernon Roberts B, Blumbergs P, Fraser R. ISSLS prize winner: The innervation of the intervertebral disc: a quantitative analysis. Spine. 2003; 28(23): 2570-6.

[162] McCarthy PW, Carruthers B, Martin D, Petts P. Immunohistochemical demonstration of sensory nerve fibers and endings in lumbar intervertebral discs of the rat. Spine. 1991; 16(6): 653-5.

[163] Willenegger S, Friess AE, Lang J, Stoffel MH. Immunohistochemical demonstration of lumbar intervertebral disc innervation in the dog. Anat Histol Embryol. 2005; 34(2): 123-8.

[164] Ozawa T, Aoki Y, Ohtori S, Takahashi K, Chiba T, Ino H, et al. The dorsal portion of the lumbar intervertebral disc is innervated primarily by small peptide containing dorsal root ganglion neurons in rats. Neurosci Lett. 2003; 344(1): 65-7.

[165] Aoki Y, Ohtori S, Takahashi K, Ino H, Takahashi Y, Chiba T, et al. Innervation of the lumbar intervertebral disc by nerve growth factor-dependent neurons related to inflammatory pain. Spine. 2004; 29(10): 1077-81.

[166] Nakamura SI, Takahashi K, Takahashi Y, Yamagata M, Moriya H. The afferent pathways of discogenic low-back pain. Evaluation of L2 spinal nerve infiltration. J Bone Joint Surg Br. 1996; 78(4): 606-12.

[167] Boswell MV, Shah RV, Everett CR, Sehgal N, Mckenzie-Brown AM, Abdi S, et al. Interventional techniques in the management of chronic spinal pain: Evidence-based practice guidelines. Pain Physician. 2007; 10(1): 7-111.

[168] Grenier N, Kressel HY, Schiebler ML, Grossman RI, Dalinka MK. Normal and degenerative posterior spinal structures: MR imaging. Radiology. 1987; 165(2): 517-25.

[169] Modic MT, Pavlicek W, Weinstein MA, Boumphrey F, Ngo F, Hardy R, et al. Magnetic resonance imaging of intervertebral disk disease. Clinical and pulse sequence considerations. Radiology. 1984; 152(1): 103-11.

[170] Pathria M, Sartoris DJ, Resnick D. Osteoarthritis of the lumbar facet joints: accuracy of oblique radiographic assessment. Radiology. 1987; 164(1): 227-30.

[171] Carrera GF, Haughton VM, Syvertsen A, Williams AL. Computed tomography of the facet joints. Radiology 1980; 134(1): 145-8. 
[172] Weishaupt D, Zanetti M, Hodler J, Boos N. Accuracy of routine MR imaging of the lumbar spine in assessment of osteoarthritis of the lumbar facets. Presented at $25^{\text {th }}$ Annual Meeting of the International Society for the Study of the Lumbar Spine, Brussels. 1998. June 9-13.

[173] Kettler A, Wilke HJ. Review of existing grading systems for cervical or lumbar disc and facet joint degeneration. Eur Spine J. 2006; 15(6): 705-18.

[174] Lane NE, Nevitt MC, Genant HK, Hochberg MC. Reliability of new indices of radiographic osteoarthritis of the hand and hip and lumbar disc degeneration. J Rheumatol. 1993; 20(11): 1911-8.

[175] Pfirrmann CW, Metzdorf A, Zanetti M, Hodler J, Boos N. Magnetic resonance classification of lumbar intervertebral disc degeneration. Spine. 2001; 26(17): 1873-8.

[176] Thompson JP, Pearce RH, Schechter MT, Adams ME, Tsang IK, Bishop PB. Preliminary evaluation of a scheme for grading the gross morphology of the human intervertebral disc. Spine. 1990; 15(5): 411-5.

[177] Kellgren JH, Jeffrey MR, Ball J. The epidemiology of chronic rheumatism. vol II: Atlas of standard radiographs of arthritis. Oxford, Blackwell Scientific Publications. 1963.

[178] Weishaupt D, Zanetti M, Boos N, Hodler J. MR imaging and CT in osteoarthritis of the lumbar facet joints. Skeletal Radiol. 1999; 28(4): 215-9.

[179] Delbeke D, Schöder H, Martin WH, Wahl RL. Hybrid imaging (SPECT/CT and PET/ CT): improving therapeutic decisions. Semin Nucl Med. 2009; 39(5): 308-40.

[180] Dutton JA, Hughes SP, Peters AM. SPECT in the management of patients with back pain and spondylolysis. Clin Nucl Med. 2000; 25(2): 93-6.

[181] Matar HE, Navalkissoor S, Berovic M, Shetty R, Garlick N, Casey AT, et al. Is hybrid imaging (SPECT/CT) a useful adjunct in the management of suspected facet joints arthropathy? Int Orthop. 2013; 37(5): 865-70.

[182] Willburger RE. Prostaglandin release from lumbar disc and facet joint tissue. Spine 1994; 19(18): 2068-70.

[183] Fernandes JC, Martel-Pelletier J, Pelletier JP. The role of cytokines in osteoarthritis pathophysiology. Biorheology 2002; 39(1-2): 237-46.

[184] Martel-Pelletier J, Alaaeddine N, Pelletier JP. Cytokines and their role in the pathophysiology of osteoarthritis. Front Biosci. 1999; 4: D694-703. Review.

[185] Wittenberg RH. In vitro release of prostaglandins and leukotrienes from synovial tissues, cartilage, and bone in degenerative joint diseases. Arthritis Rheum 1993; 36(10): 1444-50. 
[186] Igarashi A, Kikuchi S, Konno S, Olmarker K. Inflammatory cytokines released from the facet joint tissue in degenerative lumbar spinal disorders. Spine. 2004; 29(19): 2091-5.

[187] Igarashi A, Kikuchi S, Konno S. Correlation between inflammatory cytokines released from the lumbar facet joint tissue and symptoms in degenerative lumbar spinal disorders. J Orthop Sci. 2007; 12(2): 154-60.

[188] Xu D, Sun Y, Bao G, Liu W, Zhu X, Cui S, et al. MMP-1 overexpression induced by IL-1 $\beta$ : possible mechanism for inflammation in degenerative lumbar facet joint. J Orthop Sci. 2013; 18(6): 1012-9.

[189] Haro H. The role of matrix metalloproteinases and vascular endothelial growth factor in the resorption process of herniated disc. Spine J 2002; 2(5 Suppl): 106.

[190] Kato T, Haro H, Komori H, Shinomiya K. Sequential dynamics of inflammatory cytokine, angiogenesis inducing factor and matrix degrading enzymes during spontaneous resorption of the herniated disc. J Orthop Res 2004; 22(4): 895-900.

[191] Tolonen J, Grönblad M, Virri J, Seitsalo S, Rytömaa T, Karaharju E. Transforming growth factor beta receptor induction in herniated intervertebral disc tissue: an immunohistochemical study. Eur Spine J 2001; 10(2): 172-6.

[192] Matsui Y, Maeda M, Nakagami W, Iwata H. The involvement of matrix metalloproteinases and inflammation in lumbar disc herniation. Spine. 1998; 23(8): 863-9.

[193] Benneker LM, Heini PF, Anderson SE, Alini M, Ito K. Correlation of radiographic and MRI parameters to morphological and biochemical assessment of intervertebral disc degeneration. Eur Spine J. 2005; 14(1): 27-35.

[194] Kumar A. Thoracic disc prolapse in calcified discs. Orthopedics 1991; 14(1): 98-9.

[195] Gruber HE, Norton HJ, Sun Y, Hanley EN Jr. Crystal deposits in the human intervertebral disc: implications for disc degeneration. Spine J 2007; 7(4): 444-50.

[196] Lagier R, Wildi E. Incidence of chondrocalcinosis in a series of 1,000 surgically excised intervertebral disks. Rev Rheum Mal Osteoartic 1979; 46(5): 303-7.

[197] Chou C. Pathological studies on calcification of the intervertebral discs. Nihon Seikeigeka Gakkai Zasshi. 1982; 56(4): 331-45.

[198] Karamouzian S, Eskandary H, Faramarzee M, Saba M, Safizade H, Ghadipasha M, et al. Frequency of lumbar intervertebral disc calcification and angiogenesis, and their correlation with clinical, surgical, and magnetic resonance imaging findings. Spine. 2010; 35(8): 881-6.

[199] Ariga K, Miyamoto S, Nakase T, Okuda S, Meng W, Yonenobu K, et al. The relationship between apoptosis of endplate chondrocytes and aging and degeneration of the intervertebral disc. Spine. 2001; 26(22): 2414-20. 
[200] Gruber HE, Hanley EN Jr. Analysis of aging and degeneration of the human intervertebral disc. Comparison of surgical specimens with normal controls. Spine. 1998; 23(7): 751-7.

[201] Kohyama K, Saura R, Doita M, Mizuno K. Intervertebral disc cell apoptosis by nitric oxide: biological understanding of intervertebral disc degeneration. Kobe J Med Sci. 2000; 46(6): 283-95.

[202] Park JB, Lee JK, Park SJ, Kim KW, Riew KD. Mitochondrial involvement in fas-mediated apoptosis of human lumbar disc cells. J Bone Joint Surg Am. 2005; 87(6): 1338-42.

[203] Zhao CQ, Jiang LS, Dai LY. Programmed cell death in intervertebral disc degeneration. Apoptosis. 2006; 11(12): 2079-88. Review.

[204] Park JB, Chang H, Kim KW. Expression of Fas ligand and apoptosis of disc cells in herniated lumbar disc tissue. Spine. 2001; 26(6): 618-21.

[205] Zhao CQ, Zhang YH, Jiang SD, Jiang LS, Dai LY. Both endoplasmic reticulum and mitochondria are involved in disc cell apoptosis and intervertebral disc degeneration in rats. Age (Dordr). 2010; 32(2): 161-77. Review.

[206] Wang H, Liu H, Zheng ZM, Zhang KB, Wang TP, Sribastav SS, et al. Role of death receptor, mitochondrial and endoplasmic reticulum pathways in different stages of degenerative human lumbar disc. Apoptosis. 2011; 16(10): 990-1003.

[207] Kroeber M, Unglaub F, Guehring T, Nerlich A, Hadi T, Lotz J, et al. Effects of controlled dynamic disc distraction on degenerated intervertebral discs: an in vivo study on the rabbit lumbar spine model. Spine. 2005; 30(2): 181-7.

[208] Ohshima H, Tsuji H, Hirano N, Ishihara H, Katoh Y, Yamada H. Water diffusion pathway, swelling pressure, and biomechanical properties of the intervertebral disc during compression load. Spine. 1989; 14(11): 1234-44.

[209] Bibby SR, Fairbank JC, Urban MR, Urban JP. Cell viability in scoliotic discs in relation to disc deformity and nutrient levels. Spine. 2002; 27(20): 2220-8.

[210] Park JB, Park IC, Park SJ, Jin HO, Lee JK, Riew KD. Antiapoptotic effects of caspase inhibitors on rat intervertebral disc cells. J Bone Joint Surg Am. 2006; 88(4): 771-9.

[211] Ha KY, Koh IJ, Kirpalani PA, Kim YY, Cho YK, Khang GS, et al. The expression of hypoxia inducible factor-1alpha and apoptosis in herniated discs. Spine. 2006; 31(12): 1309-13.

[212] Risbud MV, Fertala J, Vresilovic EJ, Albert TJ, Shapiro IM. Nucleus pulposus cells upregulate PI3K/Akt and MEK/ERK signaling pathways under hypoxic conditions and resist apoptosis induced by serum withdrawal. Spine. 2005; 30(8): 882-9.

[213] Jones P, Gardner L, Menage J, Williams GT, Roberts S. Intervertebral disc cells as competent phagocytes in vitro: implications for cell death in disc degeneration. Arthritis Res Ther. 2008; 10(4): R86. 
